\title{
On Factors Influencing Chinese Students' English Acquisition
}

\author{
Xiao Qinghua \\ School of Foreign Languages \\ East China Jiaotong University \\ Nanchang, the People's Republic of China \\ e-mail: 1914913316@qq.com
}

\begin{abstract}
The paper explores the internal factors and external factors influencing Chinese students' English acquisition. Internal factors consist of intelligence and psychological factors. Psychological factors can be divided into learning motivation, learning attitude, personality and emotional factors. External factors consist of influence of Chinese and environmental factors. Environmental factors can be divided into family environment, school environment, team environment and social environment. Knowing the factors, teachers can teach English more skillfully and learners can learn English more effectively.
\end{abstract}

Keywords-English acquisition; intelligence; psychological factors; influence of Chinese; environmental factors

\section{INTRODUCTION}

Language, as a communication tool, plays an important role of transferring information and strengthening communication. With globalization widening, English plays an increasing important role, so English learning in every non-English speaking country is booming. In order to help people better understand the process of foreign language acquisition and enable learners to learn a foreign language effectively, linguists continuously explore language acquisition from many aspects. American linguist Noam Chomsky points out that language is a kind of innate mechanism and human's language ability is mainly decided by personal internal factors. Each healthy person has the ability to learn a language and the rules of the language are stored in the brain. Language learners can activate the potential rules of the language, find the law of the structure of the language gradually and then master the language, as long as they are constantly exposed to the specific language [1]. Lenneberg points out that human gene is the key factor of language acquisition. Language is the mature product of the brain, hence there is a critical period in language acquisition, and this period is from two years old to eleven years old [2]. Bloomfield emphasizes the essential role of environment in language acquisition. Language acquisition is not an innate ability and only in good language environment can language learners acquire language effectively. Therefore environment is the decisive factor in language acquisition [3]. This paper will discuss the factors influencing Chinese students' language acquisition which can be grouped into internal factors and external factors, and they are inseparable, mutually influencing each other and interacting with each other. Only when knowing and making these two kinds of factors work well can teachers teach English well and students learn English well.

\section{INTERNAL FACTORS}

\section{Intelligence}

Intelligence can be thought of as human's basic comprehensive ability, including observation ability, thinking ability, attention, memory, imagination and etc. As for the language talent, language experts say it should cover language coding ability, language sense ability, language memory and reasoning ability [4]. In the category of English learning, intelligence includes sensitivity to language and cognitive potential. These two are of vital importance. Without them, English learners will lose the necessary foundation and conditions of language reaction, not to mention the learning effect. At the same time, psychologists believe that intelligence is a kind of potential, although elements conducive to the growth of intelligence, including environment, knowledge, education and stimulation, do not increase a person's potential, but they can motivate the potential to a certain extent and even transform it into a real ability [5]. So, cultivating non-intelligence factors and establishing a good language learning environment are crucial for English learners when they are intelligent enough.

\section{PSYCHOLOGICAL FACTORS}

Psychological factors include students' learning motivation, attitude, personality and emotional factors, and each factor plays its unique role and meanwhile they are interconnected and interact with each other in the process of English learning.

\section{A. Learning motivation}

The English learning motivation is just the reason and purpose of studying English. From the perspective of education psychology, there are two types of reasons for learning English: (1) The first type of reasons is the surface material incentives, known as the surface motivation, such as learning for diploma and going abroad. (2) The second type of reasons is deep non-material incentives, known as deep motivation, such as learning out of interest, learning for knowledge increase. Surface motivation is not as persistent as deep motivation. Students only relying on the surface motivation to learn English often regard obtaining external material things as their ultimate goal, and they do not have high requirements for achieving knowledge about English, so 
they lack initiative and study passively. However the students who have deep motivation usually show great enthusiasm in English learning [6].

\section{Learning attitude}

The English learning attitude refers to students' cognitive, emotional and behavioral tendency in English learning. Attitude is extremely critical to the implementation of a specific target and degree of achievement. Learning motivation and learning attitude are closely associated. Learning motivation determines the learning attitude. If a student shows a positive attitude toward English, learning is a pleasure for him/her, he/she will take English learning seriously and make continuous progress. If a student shows a negative attitude toward English, he/she will muddle through the learning, which will influence the effect of learning and eventually lead to the failure of learning.

\section{B. Personality}

Personality is tightly linked with the learning achievement and the development of intelligence. Due to the differences in characteristics of personality structure, students' personalities vary from person to person. Personality directly affects the students' characteristics and their style of learning English. From a psychological perspective, personality can be segmented into introverted and extroverted. Introverted students are more cautious, they don't open their mouth before full preparation. Their slow preparation hinders their development in English listening and speaking, but they are good at writing and their writings are usually fluent and accurate. Extroverted students are active and positive in class and they usually have strong reaction ability and thinking ability. They are bold to speak, but pay little attention to the accuracy of the grammar, therefore, although speaking fluently, they often make grammatical mistakes in writing and translation. Thus it can be seen that students' personality directly impacts their language using ability and it is an essential factor to determine the success of English learning.

\section{Emotional factors}

Emotion can be a driving force or a resistance force for an English learner [7]. Positive emotion can enable students to have a keen interest in learning and then stimulate students' learning motivation. Negative emotion has two kinds of effect on English students: (1) It prevents students from maximizing opportunities of language input and language use. (2) It prevents students from absorbing and mastering the input language knowledge and thus negatively influences the quality of their output.

Among the emotional factors, interest is of paramount importance. Interest is the best teacher. Interest for English learners is an indispensable motive power. When they have an interest in learning English, students are active in behavior and can obtain psychological pleasure and sense of satisfaction more easily in the English acquisition process and then their learning desire will be stronger. In this case, interest can be changed into inner motivation, pushing students to learn more knowledge about English more actively and effectively. When they lack interest in learning English, students are passive in behavior and can not obtain the least psychological pleasure and sense of satisfaction in the English acquisition process. As time goes by, their indifference toward English will turn into dislike and even disgust, which will result in the situation that this type of students will have no desire for learning anything about English and they achieve nothing from English acquisition.

The author conducted a research to investigate the effect of interest on Chinese students' English acquisition in the university author is working. The subjects are students who are interested in English (50 students) and students who are not interested English (50 students). The research methods include observation, questionnaire and test. It is found that students who have an interest in English take initiative in learning English and show strong tendency to learn more and have consciousness of independent learning. For them, learning English is not a task, it is an emotional requirement. As a result, they make full use of their opportunity to learn and make progress (See TABLE I.). In contrast, students who lack interest in English do not have a driving force to learn English and repulse independent learning. Although the teacher pushes and guides them, they still waste learning opportunity and make no progress and even retrograde (See TABLE I.). So foresting students' interest in learning English is the key to change the situation.

TABLE I. STUDENTS' MEAN OF SCORES OF THE ENGLISH FINAL EXAM OF FOUR SEMESTERS

\begin{tabular}{|l|l|l|l|l|}
\hline \multicolumn{5}{|c|}{ Type of } \\
\cline { 2 - 5 } Students & \multicolumn{4}{|c|}{ Mean of Scores of Four Semesters } \\
\cline { 2 - 5 } & $\begin{array}{l}\text { Mean of } \\
\text { First } \\
\text { Semester }\end{array}$ & $\begin{array}{l}\text { Mean of } \\
\text { Second } \\
\text { Semester }\end{array}$ & $\begin{array}{l}\text { Mean of } \\
\text { Third } \\
\text { Semester }\end{array}$ & $\begin{array}{l}\text { Mean of } \\
\text { Fourth } \\
\text { Semester }\end{array}$ \\
\hline $\begin{array}{l}\text { students } \\
\text { having } \\
\text { interest }\end{array}$ & 76.56 & 76.83 & 78.23 & 80.15 \\
\hline $\begin{array}{l}\text { students } \\
\text { lacking } \\
\text { interest }\end{array}$ & 66.37 & 65.58 & 63.33 & 61.32 \\
\hline
\end{tabular}

In order to motivate students' interest, teachers need to make the greatest efforts to explore what the attractive points of English are and what students are interested in at first. On the basis of the attractive points of English and students' interest, teachers need to design their teaching contents elaborately. In the teaching process, teachers should not confine themselves to traditional way of teaching, instead, they should try every means to stimulate students' interest and initiative, create as many opportunities as possible to enable students to gain psychological pleasure and satisfaction and love English gradually. Interest can also arouse learners' curiosity to research English. By adopting language theories to explain interesting language points in English materials skillfully, teachers can guide students to appreciate the charms of English and light their enthusiasm to learn and research English.

In a word, teachers need to not only make students acquire knowledge but also make them enjoy the process of learning. Only when equipped with interest will students have a steady flow of passion to learn English. 


\section{EXTERNAL FACTORS}

\section{A. Influence of Chinese}

English and Chinese belong to two different language families respectively. The former belongs to Indo-European family and the latter belongs to SinoTibetan family, so there are huge differences between these two languages in phonetics, morphology, syntax and other aspects. For example, labiodental does not exist in Chinese, but exists in English. In the process of pronunciation, many Chinese students often read labiodental into bilabial due to the influence of Chinese pronunciation, which result in their difficulties in listening and speaking. This phenomenon is called negative transfer. When encountering the bilabial in English, students can grasp it very easily because bilabial also exists in Chinese. This phenomenon is called positive transfer [8]. The distinction between English and Chinese for each Chinese student is the same, but they have different effect on students, because the students' intelligence level, learning motivation, learning attitude, effort, learning environment, and other factors are not the same.

\section{B. Environmental Factors Family enviroment}

Parents are the first teachers of children and their roles can not be replaced by others in their children's life road, hence parents should actively play their role as guiders. It is critical for parents to develop their children's interest in learning. Offering children beneficial instruction to learn English at an early age is conducive to the establishment of children's positive attitude to English learning. If parents provide more understanding, encouragement and help to their children when the children are confronted with difficulties in the process of English acquisition, they will undoubtedly help their children to build confidence and motivate their language potential, consequently the children will acquire an enduring force to learn more and learn better.

\section{School environment}

School environment includes the material conditions of learning, and teachers' teaching attitude, teaching ability and teaching methods. English is a foreign language for Chinese students. The most ideal environment to learn English is English-speaking country, but it is impossible for the majority of Chinese students to learn English in a foreign country. What the teachers and students can do is to take full advantage of the present conditions to create a good environment for English acquisition. At present, the rapid development of science and technology provide students wonderful tools to learn, such as, television, mp3, ipad, computer and so on. Since teachers' teaching attitude, teaching ability and teaching methods have great impact on student. So, each teacher, first of all, should have high sense of responsibility and engage in their teaching with enthusiasm. On one hand, teachers should encourage students sincerely and help students to improve their English. On the other hand, they should work hard at improving their teaching methods and teaching ability. Only by taking a variety of ways and methods to develop students' intelligence and cultivating students' potential in the teaching process can teachers help student to improve their comprehensive English ability [9].

\section{Team environment}

In the present time, cooperative learning is advocated and has become a necessity in China's schools because collective wisdom surpasses individual wisdom and collective power is stronger than individual power to a certain degree and a lot of research show that cooperative learning will contribute to the development of language ability [10]. The influence of team environment on learners is evident. In cooperative learning of English, team plays multiply vital functions. Team can serve as a site to develop English application and communication ability. Students are required to speak in English to fulfill the task throughout the process every time an assignment is given by the teacher. Students can put what they have acquired into use and at the same time learn from each other by interacting with the other team members. Team can serve as a powerful catalyst driving students to conduct self-directed learning. In a team full of English learning atmosphere, even the student who has no interest in English is very likely to be influenced by learning passion from other members who love English and actively involve himself/herself in the completion of the given assignment. To accomplish the goal in time, team members always lay down reasonable rules and supervise and help with each other. With the supervision and help from members, each member tries their best to finish their given task. As a matter of fact, the process of finishing a task is a process of self-directed learning, self-exploration and self-improvement. Team can also function as a platform to display students' various talents. In cooperative learning, students can cultivate their potential in language and other aspects according to their interest and personality in a good team. For instance, when students are asked to carry out an investigation, they need to design questionnaires and interviews carefully, select appropriate places and ways to conduct their investigation, handle with the data collected by a right method, write their investigation report logically, and present their final work in a reasonable way. The assignment of investigation is very complicated and students need to develop various abilities to successfully fulfill the assignment including language ability, designing ability, independent thinking ability, logical thinking ability, communication ability, cooperation ability and etc. A satisfactory fruit of investigation results from all members' entire devotion of a good team. From the stage of designing the investigation to the stage of conducting the investigation and to the presentation of the fruit of the investigation, each member plays his/her own advantages and exploits his/her potential in language and other aspects. By learning with others in a good team, students can be conscious of the value of English learning and discover their own value. So establishing wonderful team environment is beneficial to students' language acquisition.

\section{E. Social environment}

Human beings have social attribute, in other words, human being are social animals. It is impossible for anyone to isolate himself/herself from the outer social environment which has impact on everyone. People in 
non-English speaking countries study English for having access to knowledge spoken or written in English, or communicating with English speakers. Nowadays we live in a society that demands a large number of talents with on their own requirements and future plan. For students, the best social environment to study English is English-speaking countries, because English-speaking social environment can provide English social and cultural contexts that contribute to students' better understanding of various aspects of English and the natural formation of English thinking ability. Meanwhile, when living in English-speaking, students can adapt themselves to communication in English, be exposed to the freshest English, come to know the development rules latent in English and love English gradually.

\section{CONCLUSION}

In sum, students are affected by the inner and outer factors in the process of English acquisition. Internal factors mainly include students' own intelligence and psychological factors. External factors mainly include the influence of Chinese and environmental factors. Teachers should, in the teaching process, adopt appropriate methods and measures to develop students' intelligence, cultivate their positive psychological factors, strengthen the positive transfer of Chinese, reduce the negative transfer of Chinese, and in the mean time provide a good learning environment for students. Parents, as the first teachers of children, should also engage in the teaching process, playing the role of motivator and guider well to encourage and help the children to find an interest in learning English and cultivate their potential in learning English. Learners themselves should, in the process of learning, correct their learning attitude, study diligently, tackle with difficulties with activity and right methods rather than just good English speaking and writing ability in all works of life. This demand is not only a pressure but also a driving force for students. Under such a social environment students can decide their degree of learning English based escape or handle difficulties with negative attitude. Only by the joint efforts from teachers, parents and students themselves can students make constant progress and improve their English ability step by step.

\section{REFERENCES}

[1] N. Chomsky, Knowledge of Language: Origin and Use. New York: Pracger Publishers, 1990.

[2] E. Lenneberg, Biological Foundations of Language. New York: Wiley and Sons, 1967.

[3] D. Brown, Principles of Language Learning and Teaching. New Jersey: Prentice-hall, Inc, 1987.

[4] Pengzhi Hu, Study on Chomsky's Philosophy of Language. Heifei: Anhui University Press, 2014

[5] Jingchuan Jiang, Intelligence Psychology. Nanjing: Southeast University Press, 2011.

[6] Boshu Li, Guocai Yan, Guozhen Ceng, HaiGen Gu, Education Psychology, 3rd, ed. Shanghai: East China Normal University, 2010.

[7] Tianjun Fu, Xiaoli Fu, "Motivation Strategies in the Computerbased College English Teaching". Journal of Hebei Normal University (Educational Science Edition), vol.12, issue 8, August, 2010, pp.115-118, doi: 10.13763/j.cnki.jhebnu.ese.2010.08.007.

[8] Mingli Yu, Yui Chang, Jiang Men, New Perspectives on Language Transfer Studies. Shanghai: Shanghai Jiaotong University Press, 2012.

[9] Li Sun, "On Non-intelligence Factors in Foreign Language Teaching," Education and Vocation, issue 20, July, 2010, pp.108109, doi: 10.13615/j.cnki.1004-3985.2010.20.011.

[10] Jing Yin, Xiaonan Zhang, "Development of Self-directed English Learning Ability of College Freshmen under Cooperative Learning Pattern", Education and Vocation, issue 20, July, 2011 pp.99-100, doc: 10.13615/j.cnki.1004-3985.2011.20.011. 